\title{
Laporan Kasus: Pembesaran gingiva yang diinduksi fenitoin
}

\author{
(Case Report: Phenitoin-induced gingival enlargement)
}

Rinawati Satrio', Primarizka Iswara Laksmi²

1 Profesi Dokter Gigi, Jurusan Kedokteran Gigi, Universitas Jenderal Soedirman, Purwokerto, Jawa Tengah

2 Bidang Penyakit Mulut, Universitas Jenderal Soedirman, Purwokerto, Jawa Tengah

\section{ABSTRAK}

Pembesaran gingiva adalah semacam manifestasi oral, yang dapat disebabkan oleh induksi obat antikonvulsan. Fenitoin adalah salah satu obat antikonvulsan yang dapat menyebabkan pembesaran gingiva. Pembesaran gingiva dalam hal ini dikembangkan sampai kelas III. Pasien sangat tergantung fenitoin dan tidak dapat didamaikan. Tujuan dari makalah ini adalah untuk mengetahui penyebab pembesaran gingiva yang diinduksi fenitoin dan pengobatannya. Seorang wanita berusia 20 tahun datang ke RSGM UNSOED untuk memeriksa gusinya yang bengkak. Riwayat pasien adalah epilepsi dan secara teratur mengonsumsi fenitoin. Pasien menggunakan $30 \mathrm{mg}$ fenobarbital, $10 \mathrm{mg}$ clobazam, $1 \mathrm{mg}$ asam folat dan $100 \mathrm{mg}$ fenitoin 2 kali sehari dengan 2 kapsul setiap kali dikonsumsi selama 4 tahun. Fenitoin sebagai obat antikonvulsan memiliki efek samping yang dapat menyebabkan pembesaran gingiva, hal ini karena fenitoin dapat meningkatkan jaringan ikat ekstraseluler, kolagen dan berserat.

Kata kunci : epilepsi, fenitoin, pembesaran gingiva

\section{ABSTRACT}

Gingival enlargement is a kind of oral manifestation, that can caused by induction of anticonvulsant drugs. Phenytoin is one of anticonvulsant drug that can caused gingival enlargement. Gingival enlargement in this case developed until grade III. The patient was highly phenytoin dependent and can't be reconciled. The aim of this paper is to find out the cause of phenytoin induced gingival enlargement and its treatment. A 20 years old woman came to RSGM UNSOED to check her swollen gums. The patient's history was epilepsy and had been regularly taking phenytoin. The patient was taking $30 \mathrm{mg}$ phenobarbital, $10 \mathrm{mg}$ clobazam, $1 \mathrm{mg}$ folic acid and $100 \mathrm{mg}$ phenytoin 2 times a day with 2 capsules each time that had been consumted for 4 years. Phenytoin as anticonvulsant drug has side effects that can caused gingival enlargement, this is because phenytoin can increase extracellular connective tissue, collagen and fibrous.

Keywords: epilepsy, gingival enlargement, phenytoin

Korespondensi (Correspondence) : Rinawati Satrio, Profesi Kedokteran Gigi, Jurusan Kedokteran Gigi, Fakultas Kedokteran, Universitas Jenderal Soedirman, Jl. Dr. Gumbreg, Mersi, Kecamatan Purwokerto Timur, Kabupaten Banyumas, Jawa Tengah 53112 , Indonesia, 08122667063 / 0281621966.

Gingiva atau gusi adalah bagian mukosa di dalam rongga mulut yang mengelilingi gigi dan menutupi lingir alveolar (alveolar ridge). Gingiva berfungsi melindungi jaringan di bawah perlekatan gigi terhadap pengaruh lingkungan rongga mulut. Gingiva merupakan bagian dari jaringan periodontal yang paling luar. Gingiva yang sehat benwarna merah muda dengan tepi tajam menyerupai kerah baju, konsistensi kenyal dengan adanya stippling. Ukuran gingiva ditentukan oleh jumlah elemen seluler, interseluler dan suplai darah. ${ }^{1,2}$

Pembesaran gingiva atau yang sering dikenal dengan istilah gingival enlargement adalah jaringan gusi yang membesar secara berlebihan di antara gigi dan atau pada daerah leher gigi. Pembesaran gingiva disebabkan oleh banyak faktor baik faktor lokal maupun sistemik, yang paling utama adalah faktor lokal yaitu plak bakteri. Tanda klinis yang muncul yaitu gingiva membesar, halus, mengkilat, konsistensi lunak, warna merah dan pinggirannya tampak membulat. ${ }^{3}$ Hal ini menimbulkan masalah estetik yang kurang baik. Berdasarkan etiopatogenesisnya, pembesaran gingiva diklasifikasikan menjadi Inflammatory Enlargement, Drug Induced Enlargment dan Enlargement Associated with Systemic Diseases. Pembesaran gingiva salah satunya diakibatkan karena konsumsi tiga kategori obat yaitu obat antikonvulsan, immunosuppressant dan calcium channel blockers. ${ }^{4}$

Pembesaran gingiva karena induksi obat dari obat antikonvulsan (antiepilepsi) yaitu fenitoin. Fenitoin masih merupakan obat pilihan pertama pada kasus epilepsi meskipun diketahui memiliki efek samping berupa pembesaran gingiva. Pembesaran gingiva biasanya muncul pada $50 \%$ pasien yang mengkonsumsi obat tersebut dan biasanya terjadi pada pasien yang masih muda. ${ }^{5}$

Pertumbuhan gingiva yang berlebihan berhubungan dengan dosis obat, lamanya pengobatan, konsentrasi dalam serum dan keberadaan plak. Gambaran klinis pembesaran gingiva yang diinduksi oleh fenitoin yaitu marginal gingiva dan papilla interdental tampak membesar dan kenyal, permukaannya tampak halus, disertai 
stippling atau berlobus, juga dapat disertai sedikit inflamasi atau tanpa inflamasi.5,6

Perawatan yang dapat dilakukan untuk kasus pembesaran gingiva diinduksi oleh fenitoin yaitu menghentikan penggunaan obat fenitoin, bedah (gingivektomi dan flap) dan non-bedah. 6

\section{KASUS}

Seorang perempuan berusia 20 tahun datang ke Rumah Sakit Gigi dan Mulut Universitas Jenderal Soedirman (RSGM UNSOED) untuk memeriksakan gusinya yang bengkak. Gusinya yang bengkak tidak sakit serta tidak mudah berdarah. Pasien mengeluh gusinya yang bengkak mengganggu secara estetika. Pasien belum pernah ke dokter gigi. Gusi bengkak sudah sejak 4 tahun yang lalu. Pasien memiliki riwayat epilepsi yang didiagnosis sejak usia 6 bulan. Pasien sempat tidak mengalami epilepsi setelah pengobatan selama 1 tahun. Pasien mengalami epilepsi kembali ketika berusia 16 tahun. Pasien mengkonsumsi obat phenobarbital $30 \mathrm{mg}$, clobazam 10mg, folic acid $1 \mathrm{mg}$ dan fenitoin $100 \mathrm{mg}$ dan dikonsumsi 2 kali sehari dengan 2 kapsul setiap kali minum secara rutin selama 4 tahun.

Hasil pemeriksaan umum pasien datang dengan keadaan compos mentis, dengan tanda-tanda vital dalam batas normal. Tekanan darah $110 / 90 \mathrm{mmHg}$, nadi $86 \mathrm{x}$ per menit dan suhu tubuh $36,5^{\circ} \mathrm{C}$. Pemeriksaan ekstra oral tidak ditemui kelainan. Hasil pemeriksaan intraoral gusi rahang atas dan gusi rahang bawah bengkak menutupi bagian papila interdental, margin gingiva pada bagian bukal, lingual dan palatal, tidak sakit dan tidak mudah berdarah (gambar).

\section{MANAJEMEN KASUS}

Manajemen yang dilakukan dalam kasus adalah tindakan pada fase 1 perawatan periodonsi yaitu perawatan non bedah antara lain.

1. Memberikan edukasi terhadap pasien mengenai pembesaran pada gingiva disebabkan efek samping dari penggunaan obat fenitoin.

2. Memberikan edukasi mengenai pentingnya menjaga kebersihan rongga mulut pasien yaitu dengan menyikat gigi dengan baik dan benar sehari 2 kali pada pagi dan malam hari sebelum tidur, dan penggunaan obat kumur antiseptik.

3. Pasien dikonsultasikan ke dokter spesialis saraf untuk evaluasi obat antikonvulsan yang dikonsumsi pasien dan apabila memungkinkan diganti dengan jenis yang lainnya.

4. Edukasi kepada pasien untuk datang ke dokter gigi secara berkala minimal bulan sekali untuk mencegah dan menjaga akumulasi plak yang dapat menyebabkan terjadinya inflamasi sekunder.

Prosedur operatif dalam kasus ini tidak dilakukan karena adanya keterbatasan secara psikologis pasien yang tidak mendukung terhadap tindakan operatif. Salah satunya adalah akan memicu kekambuhan serangan epilepsi pada saat tindakan operatif. Faktor pencetus kekambuhan serangan epilepsi pada pasien bisa dikarenakan stress, kelelahan, puasa, dan kurang tidur. Akumulasi plak yang tidak terkontrol menjadi salah satu penyebab pembesaran gingiva pada pasien sehingga mencapai Grade III. Rekonsiliasi obat pada kasus ini tidak dapat dilakukan karena dokter spesialis saraf tidak mengizinkan untuk adanya penggantian obat fenitoin dengan obat lainnya.

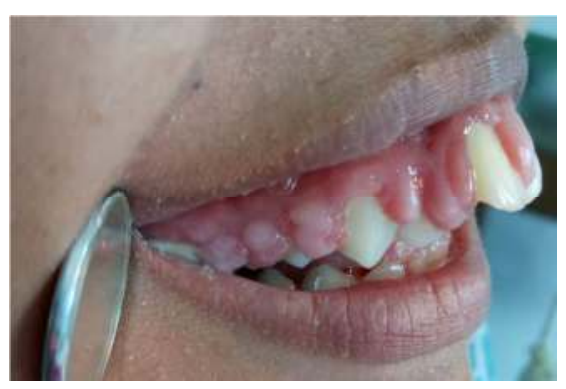

Gambar 1. Gambaran Klinis Pasien Gingival Enlargement Menutupi Permukaan Gigi pada Bagian Bukal Posterior 


\section{PEMBAHASAN}

Epilepsi adalah suatu kumpulan gejala dan tanda-tanda klinis yang muncul disebabkan oleh gangguan fungsi otak secara intermiten yang terjadi akibat lepasnya muatan listrik abnormal dengan berbagai macam etiologi. Serangan pada epilepsi dikenal dengan nama epileptic seizure adalah manifestasi klinik yang serupa dan berulang secara paroksisimal, yang disebabkan oleh hiperaktivitas listrik sekelompok sel syaraf diotak yang spontan dan bukan disebabkan oleh suatu penyakit otak akut. 5

Obat antikonvulsan seperti fenitoin merupakan obat pilihan pertama pada kasus epilepsi meskipun diketahui memiliki efek samping berupa pembesaran gingiva. Pembesaran gingiva merupakan hasil dari perubahan inflamsi akut atau kronis. Perubahan kronis lebih umum terjadi. 5 Gambaran klinis inflamasi kronis pembesaran gingiva adalah pada tahap awal merupakan tonjolan sekitar gigi pada papila dan marginal gingival. Tonjolan tersebut dapat bertambah ukurannya sampai menutup mahkota. Pembesaran dapat terjadi secara lokal ataupun general, progresnya lambat dan tidak sakit, kecuali pada infeksi akut atau trauma. 6,7

Keparahan gingiva diklasifikasikan menjadi Grade I: pembesaran sebatas papila interdental. Grade II: Pembesaran menutupi papila interdental dan margin gingiva. Grade III: pembesaran menutupi sepertiga atau lebih mahkota klinis gigi. Pembesaran pada kasus ini disebabkan oleh adanya induksi dari fenitoin. Keparahan gingiva pada kasus ini termasuk ke dalam Grade III yaitu pembesaran gingiva yang menutupi sepertiga atau lebih mahkota klinis gigi.'

Obat antikonvulsan selain fenitoin antara lain fenobarbital, pyrimidone, vigabatryn. Fenitoin diketahui mampu menginduksi pertumbuhan fibroblas gingiva bersamaan dengan komponen inflamasi. Patogenesis pembesaran gingiva yang disebabkan oleh fenitoin yang mampu menginduksi penurunan masuknya sel $\mathrm{Ca}^{+}$.

Fenitoin menghambat penyerapan asam folat, sehingga membatasi produksi kolagenase aktif. ${ }^{6}$ Ketidakseimbangan ini karena adanya interaksi TNF-a dengan fenitoin menyebabkan MMP, bersama integrin menginduksi akumulasi kolagen sementara enzim kolagenase rusak dan tidak dapat melakukan degradasi. 6.7

Myofibroblast dan sitokin diinduksi oleh fenitoin. Fibroblas yang diaktifkan fenitoin menghasilkan IL-6, IL-1, dan IL-8 dalam jumlah besar. Mediator tersebut mampu mengaktifkan proliferasi sel $\mathrm{T}$ dan adanya neutrofil di jaringan, membangun interaksi langsung antara sistem kekebalan tubuh dan jaringan ikat.7Selain itu plak gigi dalam etiologi pada pembesaran gingiva yang disebabkan oleh fenitoin adalah sebagai respon inflamasi lokal sehingga gingiva mengalami pertumbuhan yang cepat. 7.8

Penatalaksanaan untuk pasien pembesaran gingiva yang disebabkan oleh penggunaan obat yaitu, 1) penghentian atau penggantian obat, misalnya penggantian obat dapat dilakukan dengan mengganti fenitoin dengan carbamazephine dan valproic acid, 2) kontrol plak, drug-induced enlargment diasosiasikan dengan poket pseudo atau false poket biasanya karena adanya akumulasi plak, 3) surgical therapy, dapat dilakukan berupa bedah yaitu gingivektomi ataupun flap periodontal.2,8

Pembesaran gingiva dapat disebabkan salah satunya oleh drug induced enlargement. Pada kasus pembesaran gingiva disebabkan oleh penggunaan antikonvulsan berupa fenitoin. Fenitoin menginduksi $\mathrm{Ca}^{2+}$ sehingga menghambat penyerapan asam folat, selain itu fenitoin meningkatkan ekstraseluler seperti jaringan ikat, kolagen dan fibroblast. Pada kasus tidak dilakukan penatalaksanaan berupa tindakan operatif karena akan mengakibatkan serangan epilepsi pada saat tindakan. Pasien hanya di edukasi untuk mencegah terjadinya akumulasi plak.

\section{DAFTAR PUSTAKA}

1. Newman MG., Takei HH., Carranza FA.Clinical Periodontology $11^{\text {th }}$ 9th edition. 2012.Philadelphia: WB Saunders Co.p . 7494

2. The American Academy operiodontology., 2011, Glossary of periodontal term $4^{\text {th }}$ Chicago.

3. Chouksey A., Awasthi, N., Rai, J., Chaudhary, A. Association of DrugInduced Gingival Enlargment (Calcium Channel Blocker) and Local Factors: Who is the Culprit?. Int Dent \& Med Journal. 2017; 3 (1): 1-4.

4. Bajoria, A.A., Asha, M.L Babshet, M., Patil, P.Sukhija, P. Gingival Enlargment: Revisited: A Case Series, IJJS Case Report \& Reviews. 2015; 1 (3): 20-25.

5. Sander, J, and S. D. Shorvon. Epidemiology of the epilepsies. Journal of Neurology Neurosurgery and Psychiatry. 2015; 61(5), 433-443,

6. Guncu, F. Cxaglayan, A. Dincxel, A. Bozkurt, S. Sayg, and E. Karabulut.Plasma and gingival crevicular fluid phenytoin concentrations as risk factors for gingival overgrowth.Journal of Periodontology. 2015; 77.

7. Suzuki, A. Yoshimura, Y. Ozaki, T. Kaneko, and $Y$. Hara. Cyclosporin A and phenytoin modulate inflammatory responses. Journal 
of Dental Research. 2016; 88( 12), 11311136.

8. Brunet, L, J. Miranda, P. Roset, L. Berini, M. Farre, and C.' Mendieta. Prevalence and risk of gingival enlargement in patients treated with anticonvulsant drugs. The European Journal of Clinical Investigation. 2014; 31 (9), 781-788. 